\title{
Pozyskiwanie studentów zagranicznych do uczelni krajów półperyferyjnych. Badanie porównawcze Norwegii, Polski i Portugalii ${ }^{1}$
}

STRESZCZENIE: W artykule zbadano podejścia zastosowane w celu przyciągnięcia międzynarodowych studentów w trzech krajach leżących na obrzeżach Europy (Europejskiego Obszaru Gospodarczego): Norwegii, Polski i Portugalii. Kraje te, uważane za półperyferyjne pod względem rekrutacji studentów z zagranicy, mają mniejsze tradycje w zakresie mobilności przyjazdowej niż kraje, które są głównymi rekrutującymi i które były przedmiotem wcześniejszych badań dotyczących przyciągania studentów z zagranicy. W artykule przeanalizowano krajowe polityki i strategie, koncentrując się na ich powstawaniu, racjonalnych rozwiązaniach i instrumentach. Badanie ma charakter porównawczy i ma na celu znalezienie podobieństw i różnic w podejściu tych krajów do zmieniającego się globalnego środowiska szkolnictwa wyższego. Głównym wynikiem analiz jest ustalenie, że kraje półperyferyjne wydają się stosować inne strategie i uciekać się do innych przewag komparatywnych niż najwięksi rekrutujący. Wyniki podkreślają potrzebę określenia przez te kraje ich szczególnych zdolności przyciągania i atutów, a także celowego wyboru regionów, w których będą rekrutować studentów.

SŁOWA KLUCZOWE: studenci zagraniczni, strategie rekrutacji, peryferia, Norwegia, Polska, Portugalia

\section{Wprowadzenie}

W niniejszym opracowaniu zbadano strategie zastosowane w celu przyciągnięcia zagranicznych studentów do trzech krajów z peryferii Europejskiego Obszaru Gospodarczego: Norwegii, Polski i Portugalii. Jego celem jest zbadanie, w jakich okolicznościach, dlaczego i w jaki sposób rządy w tych krajach traktują międzynarodową rekrutację studentów jako wyraźny cel polityki szkolnictwa wyższego. Koncepcja centrum i peryferii jest inspirowana teorią „systemu światowego” Immanuela Wallersteina

1 Artykuł ukazał się w periodyku Higher Education Policy (2019). https://doi.org/10.1057/s41307019-00135-3. 
(Wallerstein 1974), która definiuje kraje centrum, półperyferyjne i peryferyjne w oparciu o strukturę ich gospodarki. W naszej pracy przenosimy tę taksonomię do sfery edukacji międzynarodowej, o czym świadczy napływ i odpływ studentów.

W związku z tym, dla potrzeb niniejszej analizy, uważamy, że kraje znajdują się w centrum (kraje centralne), jeśli są głównymi „importerami” międzynarodowych studentów, a więc popularnymi (globalnymi) miejscami docelowymi (np. USA, Wielka Brytania, Australia, ale także Francja, Niemcy, Holandia czy Szwajcaria). Kraje półperyferyjne to kraje o bardziej zrównoważonym napływie i odpływie studentów można je uznać za „eksporterów” i „importerów” studentów zagranicznych. Nie są oni kluczowymi graczami na rynku studentów zagranicznych, znajdując się dalej od centrum, jednak nadal wykazują zdolność przyciągania studentów zagranicznych, choć w mniejszym stopniu niż kraje centralne. Norwegia, Polska i Portugalia należą właśnie do tej kategorii. Wreszcie w naszej analizie krajami peryferyjnymi są te, które nie przyciągają studentów zagranicznych i są głównie „eksporterami” zaopatrującymi światowy rynek w studentów, którzy decydują się na studia za granicą ze względu na ograniczone możliwości instytucjonalne, słabo rozwinięte systemy szkolnictwa wyższego, niską jakość kształcenia lub względy ekonomiczne/polityczne.

Badanie to opiera się na założeniu, że kraje półperyferyjne muszą opracować różne strategie przyciągania międzynarodowych studentów ze względu na ich niekorzystną pozycję wyjściową na rynku światowym oraz ze względu na to, że często brakuje im tradycji w rekrutacji i kształceniu obcokrajowców. Według Urbanoviča, Wilkinsa i Huismana (2014) małe kraje stoją przed odmiennymi wyzwaniami w porównaniu z centralnymi krajami prowadzącymi rekrutację od lat. Po pierwsze później weszły na międzynarodowy rynek studencki, co oznacza brak „przewagi pierwszego oferenta" krajów takich jak Wielka Brytania, Stany Zjednoczone, Australia czy Kanada. Po drugie dla wielu krajów pół-peryferyjnych ograniczone zasoby finansowe i brak ekonomii skali może oznaczać brak możliwości inwestowania w infrastrukturę (np. obiekty noclegowe i biblioteczne), marketing/markę i zasoby ludzkie (jak to może mieć miejsce w przypadku Portugalii i Polski, ale nie Norwegii). Międzynarodowa rekrutacja studentów w krajach, które tradycyjnie nie znajdują się w czołówce międzynarodowego rynku rekrutacyjnego, nie jest w pełni zbadana (Franca, Alves i Padilla 2018). Badanie to - o charakterze porównawczym - ma na celu znalezienie cech wspólnych, jak również cech narodowych i wyróżniających przewag, które każdy kraj wykorzystuje w celu przyjęcia większej liczby studentów zagranicznych. Od czasu, gdy rekrutacja weszła na peryferia globalnego rynku edukacyjnego (Cantwell 2017), jest ona niewystarczająco dobrze zbadana w tych kontekstach. Celem niniejszego opracowania jest wniesienie wkładu w istniejący zasób wiedzy poprzez zbadanie strategii opracowanych przez kraje półperyferyjne w celu zwiększenia liczby zagranicznych studentów. 
W artykule przeprowadzono analizę porównawczą polityki i strategii rekrutacji w następujących aspektach: (a) czasu i okoliczności, w których międzynarodowa rekrutacja studentów stała się celem politycznym o wysokim priorytecie; (b) sposobów legitymizacji polityki trzech analizowanych krajów oraz (c) instrumentów, które rządy zastosowały w celu wspierania rekrutacji studentów zagranicznych. $\mathrm{W}$ artykule przedstawiono również końcową refleksję nad konkretnymi działaniami podejmowanymi w tym zakresie przez kraje półperyferyjne, a także przeanalizowano argumenty, które każdy kraj wykorzystuje i promuje jako przewagę konkurencyjną. Analiza ta ogranicza się do polityki rządowej, chociaż uznaje się, że działalność ta obejmuje również inne podmioty. Niezależnie od tego rząd odgrywa wiodącą rolę, ustalając zasady i odpowiednio ułatwiając korzystanie z zasobów publicznych. W artykule określono również główne podmioty polityczne zaangażowane we wdrażanie strategii krajowych (takie jak agencje promujące kraj jako miejsce odbywania studiów, stowarzyszenia uniwersyteckie, biura zagraniczne itp.). Z metodologicznego punktu widzenia praca wykorzystuje analizę dokumentów i ocenia krajowe strategie, dokumenty polityczne i przepisy krajowe, które mają (bezpośredni lub pośredni) wpływ na rekrutację studentów zagranicznych.

\section{Międzynarodowa rekrutacja studentów - kontekst teoretyczny}

Na całym świecie liczba studentów kształcących się za granicą wzrosła z 3 mln w $2005 \mathrm{r}$. do 4,6 mln w 2015 r. (OECD 2017). Świadome potencjału gospodarczego, jakie niesie szkolnictwo wyższe, wiele rządów opracowało politykę i zachęty dla uczelni w celu przyciągnięcia międzynarodowych studentów (Cremonini i Antonowicz 2009; Stier 2004).

Kraje anglojęzyczne są głównymi miejscami docelowymi dla studentów, którzy podejmują naukę za granicą (Barnett i in. 2016; OECD 2017). Według OECD krajem, który przyciąga największą liczbę studentów zagranicznych są Stany Zjednoczone. W Europie najbardziej popularnymi krajami docelowymi są Wielka Brytania, Francja i Niemcy (OECD 2017). Jednak mniejsze kraje europejskie stały się ostatnio świadome możliwości, jakie stwarza rosnący napływ studentów z zagranicy (Cox 2013; Kondakci 2011; Mosneaga i Agergaard 2012), traktowany jako sposób na zrekompensowanie pogarszającej się sytuacji demograficznej i malejącego finansowania publicznego. Mobilność studentów jest rzeczywiście najczęstszą formą umiedzyanrodowienia uczelni. Badanie przeprowadzone w 38 krajach europejskich (Europejskie Stowarzyszenie Uniwersytetów 2013) wykazało, że przyciągnięcie międzynarodowych studentów jest najwyższym priorytetem w kontekście internacjonalizacji.

W sprawozdaniu Parlamentu Europejskiego w sprawie internacjonalizacji szkolnictwa wyższego (de Wit i in. 2015) stwierdza się, że kraje mają kilka wspólnych 
celów, takich jak: zwiększenie reputacji (w rankingach), widoczności i konkurencyjności; konkurencja o utalentowanych studentów i naukowców; krótko- i/lub długoterminowe korzyści gospodarcze oraz względy demograficzne. Dlatego też, w kontekście globalizującego się szkolnictwa wyższego (HE) i malejącej liczby tradycyjnych studentów krajowych w całej Europie (de Wit i in. 2015), rekrutacja studentów z zagranicy mogłaby, w perspektywie średnio- i długoterminowej, zapewnić trwałość działania i rozwój wielu uczelni. Aby usystematyzować naszą analizę poszukiwania uzasadnienia dla rekrutacji studentów z zagranicy, stosujemy ramy analityczne, które zostały rozwinięte w kilku poprzednich badaniach i które identyfikują cztery typy racjonalności polityki internacjonalizacji (Blumenthal et al. 1996; van der Wende 1997; Knight i de Wit 1995). Racjonalne przesłanki kulturowe odzwierciedlają troskę o różnorodność kulturową i poprawę zrozumienia i komunikacji międzykulturowej studentów, ale mogą być również związane z używaniem wspólnego języka. Racjonalizacja polityczna koncentruje się na statusie i roli kraju w świecie, dlatego też z perspektywy narodowej staje się bardzo istotna. Racjonalne przesłanki naukowe są obecne, gdy celem jest osiągnięcie międzynarodowych standardów nauczania i badań naukowych, przy założeniu, że umiędzynarodowienie uczelni wniesie wartość dodaną do poziomu kształcenia i przyczyni się do podniesienia jakości realizowanych badań. Wreszcie, racjonalizacje ekonomiczne są obecne, gdy internacjonalizacja staje się zorientowana na rynek i jest postrzegana jako sposób generowania dochodów lub przyciągania przyszłych wysoko wykwalifikowanych pracowników.

Racjonalna polityka ujawnia jedynie motywacje i intencje rządów. Z tego powodu ważne jest również instrumentarium, które rządy stosują w celu wdrożenia, tj. instrumenty polityki stosowane w celu zwiększenia liczby studentów zagranicznych, ponieważ uzupełniają one analizę międzynarodowej polityki rekrutacji studentów o konkretne inicjatywy. W związku z tym artykuł porusza dwie kwestie: a) przesłanki lub powody, dla których rządy krajowe nadały priorytet polityczny międzynarodowej rekrutacji studentów; b) instrumenty polityczne oraz inicjatywy polityczne służące realizacji tego celu. Aby odpowiedzieć na to drugie pytanie, wykorzystujemy taksonomię instrumentów polityki Everta Vedunga (1998) według stopnia „siły autorytatywnej”: przepisów (form przymusu), środków ekonomicznych (marchewki) i informacji (kazań). Rozporządzenia (przymus) to „środki podejmowane przez jednostki rządowe w celu wywierania wpływu na ludzi za pomocą sformułowanych zasad i dyrektyw, które upoważniają odbiorców do działania zgodnie z tym, co jest nakazane w tych zasadach i dyrektywach" (Vedung 1998: 31). Do tej kategorii mogą należeć ustawy i dekrety, które kierują działalnością instytucjonalną w stronę rekrutacji międzynarodowej. Środki ekonomiczne (marchewki) pozostawiają odbiorcom polityki decyzję o sposobie działania. Jednakże zachęty finansowe lub rzeczowe skłaniają ich do wyboru opcji preferowanej przez organ 
autorytatywny, ponieważ „środki ekonomiczne sprawiają, że prowadzenie niektórych działań jest tańsze lub droższe pod względem pieniędzy, czasu, wysiłku i innych wartości” (Vedung 1998: 32). W tym sensie przykładem są korzyści ekonomiczne płynące z rekrutacji studentów z zagranicy. Informacja (kazania) definiowana jest jako „perswazja moralna” i obejmuje „próby wywierania wpływu na ludzi poprzez transfer wiedzy, przekazywanie uzasadnionych argumentów i perswazję". Vedung podkreśla, że informacji nie należy rozumieć wyłącznie jako obiektywnej wiedzy i faktów; obejmuje ona również „zalecenia dotyczące zachowania i zachowania obywateli” (Vedung 1998: 33). Przykładem mogą być strategie krajowe, które zalecają pożądany kierunek działań oraz kampanie marketingowe kraju. Co ważne, Vedung omawia również wybór „niepodejmowania żadnych działań”, nieingerencji lub polityki „,bez polityki” (Antonowicz 2012), w którym to przypadku rekrutacja międzynarodowa jest po prostu modną retoryką polityczną.

To, w jaki sposób zagraniczni studenci dokonują wyborów kierunków studiów i co determinuje kierunek ich migracji, staje się niezbędne do formułowania i realizacji polityki publicznej. Biorąc pod uwagę intensywną konkurencję na rynku (Varghese 2008), marketing i akademicki branding stały się ważne dla wpływania na wybór i podejmowanie decyzji edukacyjnych przez potencjalnych kandydatów (Drori 2015; Nicolescu 2009). Przy podejmowaniu decyzji o studiowaniu za granicą wybór kraju zwykle poprzedza wybór instytucji (Llewellyn-Smith i McCabe 2008; Mazzarol i Soutar 2002). Według OECD (2016) istnieją cztery podstawowe przesłanki wyboru kraju przyjmującego przez studentów: język wykładowy, jakość oferowanych programów, wysokość opłaty za naukę i polityka imigracyjna. Badania empiryczne dotyczące podstawowych wymiarów wzorców mobilności (Caruso i de Wit 2015; Beine i in. 2014) określiły również inne czynniki: wydatki na studenta, postrzeganie bezpieczeństwa, otwartość gospodarki, warunki ekonomiczne kraju przyjmującego i sieć migrantów w kraju przyjmującym. Perkins i Neumayer (2014) twierdzą, że dochody w krajach docelowych, wraz z relacjami tworzonymi przez powiązania kolonialne, wspólny język i wcześniej istniejące zasoby migrantów mają znacznie większy wpływ niż jakość edukacji. W odniesieniu do krajów peryferyjnych Kondakci (2011) sugeruje, że charakter kulturowej, politycznej i historycznej bliskości pomiędzy krajem pochodzenia i krajem przyjmującym determinuje wielkość i kierunek napływającej mobilności studentów. Tak więc, pomimo ogólnego przepływu mobilności z krajów słabiej rozwiniętych gospodarczo do krajów rozwiniętych gospodarczo, regionalne węzły na peryferiach są w stanie przyciągnąc studentów pochodzących w dużej mierze z innych krajów peryferyjnych (Kondakci 2011). Z kolei Börjesson (2017) identyfikuje trzy różne wzorce mobilności i bieguny rekrutacji: biegun Pacyfiku, opisujący przepływy studentów z Azji do Ameryki Północnej, Oceanii i Wielkiej Brytanii; biegun środkowoeuropejski, obejmujący mobilność wewnątrzeuropejską; 
oraz biegun francusko-iberyjski, opisujący rekrutację z byłych kolonii do Europy Południowo-Zachodniej. Odzwierciedlają one różne logiki rekrutacji: logikę rynku, logikę bliskości i logikę kolonialną.

\section{Dane i metody}

Badanie zostało oparte na analizie źródeł i danych zastanych. Dokonano tego w oparciu o studia nad dokumentami dotyczącymi polityki, prawodawstwa, sprawozdań, oświadczeń lub stanowisk, wydanych przez organy rządowe lub inne właściwe organizacje, które zajmowały się internacjonalizacją w ogóle, a w szczególności rekrutacją studentów (zob. tabela 1). Wybrane dokumenty zostały poddane analizie tematycznej dotyczącej strategii, legitymizacji oraz instrumentów stosowanych w celu zwiększenia atrakcyjności tych krajów dla studentów zagranicznych. Analiza ta pozwoliła również na identyfikację głównych aktorów zaangażowanych w międzynarodową rekrutację studentów.

Tabela 1. Analizowane dokumenty związane z umiędzynarodowieniem szkolnictwa wyższego

\begin{tabular}{|c|l|}
\hline Kraj & \multicolumn{1}{|c|}{ Dokument polityczny } \\
\hline Norwegia & $\begin{array}{l}\text { Om høyere utdanning [On Higher Education] (1985). White paper no 19. Minis- } \\
\text { try of Education. } \\
\text { Grenseløs læring [Borderless Knowledge] (1989). Green paper 1989:13. } \\
\text { Gjør din plikt, krev din rett. Kvalitetsreform av høyere utdanning [Do Your } \\
\text { Duty, Demand Your Rights. Quality Reform in Higher Education] (2001). White } \\
\text { paper no 27. } \\
\text { Internasjonalisering av utdanning [Internationalisation of Education] (2009) } \\
\text { White paper no 14. } \\
\text { Kultur for kvalitet i høyere utdanning [Culture for Quality in Higher Education] } \\
\text { (2017). White paper no 16. }\end{array}$ \\
\hline $\begin{array}{l}\text { Partnerstwo dla wiedzy. Reforma szkolnictwa wyższego w Polsce (2009). Mini- } \\
\text { sterstwo Nauki i Szkolnictwa Wyższego (MNiSW). } \\
\text { Założenia do nowelizacji ustawy - Prawo o szkolnictwie wyższym oraz ustawy } \\
\text { o stopniach naukowych i tytule naukowym oraz o stopniach i tytule w zakresie } \\
\text { sztuki (2009). MNiSW. } \\
\text { Program umiędzynarodowienia szkolnictwa wyższego (2015). MNiSW, Warszawa. } \\
\text { Rozporządzenie MNiSW w sprawie statutu Narodowej Agencji Wymiany Akade- } \\
\text { mickiej (2017). MNiSW. }\end{array}$ \\
\hline
\end{tabular}




\begin{tabular}{|c|l|}
\hline Kraj & \multicolumn{1}{c|}{ Dokument polityczny } \\
\hline Portugalia & $\begin{array}{l}\text { Uma estratégia para a internacionalização do ensino superior português [A Strate- } \\
\text { gy for the Internationalisation of Portuguese Higher Education] (2014). Ministry } \\
\text { of Regional Development and Ministry of Education. } \\
\text { Decree-Law 36/2014: Statute of the International Student (2014). Ministry } \\
\text { of Education and Science. }\end{array}$ \\
$\begin{array}{l}\text { Resolução do Conselho de Ministros } n^{0} \text { 47/2015. [Resolution of the Council } \\
\text { of Ministers]. } \\
\text { Resolução do Conselho de Ministros } n^{0} \text { 78/2016. [Resolution of the Council } \\
\text { of Ministers]. } \\
\text { PortugalGlobal: A crescente internacionalização do ensino superior português. } \\
\text { (2017). AICEP (Portuguese Agency for Foreign Investment and Trade). }\end{array}$ \\
\hline
\end{tabular}

\section{Dokumenty polityki krajowej}

Żadna międzynarodowa baza danych dla tych trzech krajów nie została uznana za wystarczająco dokładną, aby porównać tendencje w przepływie studentów do Norwegii, Polski i Portugalii. Nawet jeśli dane były łatwo dostępne do porównań (UNESCO-UIS), zaobserwowano różnice pomiędzy zawartymi w nich liczbami a statystykami krajowymi. $Z$ tego powodu liczby przedstawione $\mathrm{w}$ niniejszym opracowaniu pochodzą z baz danych, czasem krajowych, a czasem międzynarodowych, co do których wiarygodności autorzy mieli zaufanie w oparciu o ich wiedzę na temat krajowego systemu szkolnictwa wyższego. Liczby te stanowią ważny punkt odniesienia dla decydentów politycznych, co jest istotnym aspektem legitymizującym je w rozwoju polityki.

W Norwegii informacje o liczbie studentów uzyskano z Norweskiego Urzędu Statystycznego, Norweskiego Centrum Współpracy Międzynarodowej w dziedzinie edukacji (SIU) oraz rejestru doktorantów Nordyckiego Instytutu Badań Naukowych i Edukacji (Sarpebakken 2016). W Polsce dane pochodzą z Głównego Urzędu Statystycznego (GUS). W Portugalii źródłem informacji jest Dyrekcja Generalna ds. Edukacji i Statystyk Naukowych (DGEEC). Mimo że statystyki krajowe są dostępne dopiero od 2013 r., wzrost liczby studentów zagranicznych jest widoczny nawet w tym krótkim okresie czasu (zob. załącznik 1 zawierający przegląd studentów zagranicznych w tych trzech krajach). W niniejszym dokumencie „studenci zagraniczni” są definiowani jako studenci studiów wyższych w zakresie mobilności pełnocyklowej zarówno na poziomie licencjackim, jak i studiów magisterskich.

W Norwegii studenci zagraniczni stanowią około 10\% wszystkich studentów na poziomie licencjackim i magisterskim (SIU 2016). Odsetek ten jest wyższy na poziomie studiów doktoranckich, gdzie studenci zagraniczni stanowią 39\% wszystkich absolwentów studiów doktoranckich w 2017 r. (NIFU 2018). Liczba studentów 
zagranicznych gwałtownie wzrosła na początku XXI wieku (Wiers-Jenssen 2018), ale w ostatnich latach dynamika ta uległa spowolnieniu. Jak pokazuje tabela w załączniku (A1), studenci zagraniczni w Norwegii pochodzą z dużej liczby krajów. Wielu z nich pochodzi z krajów sąsiednich o podobnym języku (Szwecja i Dania), a rosnąca ich liczba z Niemiec. Dobrze reprezentowani są również studenci z Chin, Rosji i Polski.

W Polsce studenci zagraniczni stanowią około 4,9 \% całej populacji studentów, ale dopiero od niedawna liczba ta dynamicznie rośnie i osiągnęła najwyższy poziom w historii (GUS 2016).

Przez wiele lat liczba studentów z zagranicy wykazywała skromny, ale stabilny wzrost, sytuacja zmieniła się dopiero w $2005 \mathrm{r}$. Siłą napędową internacjonalizacji są studenci z Ukrainy (54\%) (patrz załącznik). Liczba studentów zagranicznych jest w równym stopniu rozłożona: programy licencjackie (i medyczne) - 5,1\%, następnie programy magisterskie $-4,4 \%$, a najmniej, bo 3,3\%, studentów zagranicznych jest zarejestrowanych na studiach doktoranckich (GUS 2015). Ten ostatni wynik jest najprawdopodobniej efektem ubocznym krytycznie niskiego poziomu wydatków publicznych na badania naukowe.

W Portugalii w 2014 r. studenci zagraniczni stanowili 4,1\% wszystkich studentów (OECD 2016). Największy odsetek (15,8\%) odnotowano w programach doktoranckich, a następnie w programach magisterskich $(4,9 \%)$ i licencjackich $(2,6 \%)$. W tym samym roku, w krajach OECD, popularność Portugalii wśród studentów zagranicznych wyniosła 1\% w porównaniu z 0,51\% w 2011 r. (MADR/MEC 2014), co sugeruje dwukrotny wzrost w ciągu trzech lat. Około dwie trzecie międzynarodowych studentów pochodzi z krajów portugalskojęzycznych (byłych portugalskich kolonii). Poza tym w latach 2014-2017 trzykrotnie wzrosła liczba studentów chińskich (zob. załącznik), ponieważ uniwersytety, zarówno indywidualnie i przy pomocy organizacji przedstawicielskich, zintensyfikowały wysiłki mające na celu budowanie tam lepszego wizerunku. Poniższe rozdziały przedstawiają główne wnioski dotyczące czasu i okoliczności, w których międzynarodowa rekrutacja studentów stała się celem politycznym o wysokim priorytecie, legitymizację dla zmiany polityki w trzech analizowanych krajach oraz instrumenty, które rządy zastosowały w celu wspierania rekrutacji studentów zagranicznych.

\section{Pojawienie się międzynarodowej rekrutacji studentów jako priorytetu politycznego}

Rekrutacja zagranicznych studentów, jako symbol internacjonalizacji szkolnictwa wyższego, stała się politycznym priorytetem w Polsce i Portugalii dopiero w ostatnich latach, podczas gdy w Norwegii była priorytetem od końca lat 80 . W tym czasie 
głównym narodowym agencjom zajmującym się rekrutacją studentów udało się już opracować własne strategie i zbudować kanały rekrutacji. Analizowane kraje półperyferyjne weszły na światowy rynek studencki później niż kraje centralne. W Polsce i w Norwegii zmiany w kierunku internacjonalizacji wpisały się w szerszy program reform mających na celu modernizację szkolnictwa wyższego, Reformę Jakości w Norwegii (2003) i Partnerstwo dla Wiedzy (MNiSW 2009) w Polsce, natomiast w Portugalii zmianę tę naznaczyła publikacja krajowej Strategii Internacjonalizacji Szkolnictwa Wyższego (MADR/MEC 2014). We wszystkich przypadkach inicjatywa należała do rządów centralnych, które uruchomiły mechanizmy mające swoje dalsze konsekwencje.

Norwegia rozpoczęła dyskusję na temat internacjonalizacji i rekrutacji studentów z zagranicy w latach 80. Mobilność studentów postrzegana była jako celowa strategia umiędzynarodowienia szkolnictwa wyższego, a celem stało się radykalne zwiększenie liczby studentów zagranicznych (Ministerstwo Edukacji 1985). Rząd powołał komisję, której zadaniem było rozważenie priorytetów w zakresie rekrutacji obcokrajowców, a rekomendacje zostały opublikowane w raporcie (NOU 1989: 13).

Głównymi zaleceniami było stworzenie większej liczby programów w języku angielskim i ustanowienie centrum umiędzynarodowienia edukacji. Fakt, że Norwegia przystąpiła do programu ERASMUS już w 1989 r. (mimo że nie jest członkiem Unii Europejskiej) jest oznaką jej zaangażowania na rzecz internacjonalizacji w szkolnictwie wyższym. Zostało to potwierdzone podpisaniem deklaracji bolońskiej w 1999 r., a następnie reformą szkolnictwa wyższego zwaną „reformą jakości” z 2003 r. wdrażającą nową strukturę dyplomów zgodnie z zasadami bolońskimi (Ministerstwo Edukacji 2001). Pozytywne efekty przyciągania studentów z zagranicy, takie jak uwzględnienie szerszego spektrum perspektyw w szkolnictwie wyższym, zostały podkreślone w Białej Księdze na temat internacjonalizacji szkolnictwa wyższego (Ministerstwo Edukacji 2009) i powtórzone w Białej Księdze na temat jakości w szkolnictwie wyższym (Ministerstwo Edukacji 2017).

W Polsce rzeczywista zmiana polityki w tym zakresie nastąpiła w 2009 roku. Wcześniej internacjonalizacja pozostawała na marginesie polityki wobec szkolnictwa wyższego, która koncentrowała się głównie na przeciwdziałaniu niezamierzonym konsekwencjom szybkiej ekspansji (Pinheiro i Antonowicz 2014). Brak studentów zagranicznych wynikał z historycznej spuścizny polskiego szkolnictwa wyższego, a mianowicie bliskich związków z państwem narodowym, które nadawały priorytet skupieniu się na studentach krajowych. Pierwsze syndromy zmian pojawiły się wraz z procesem bolońskim, który duży nacisk kładł na międzynarodową mobilność i wyzwalał (początkowo powoli) proces internacjonalizacji w domu (ang. internationalization at home). Stopniowo zmieniała się także polityka rządu, głównie ze względu na zewnętrzną presję normatywną (Altbach 2013) związaną z rosnącą popularnością 
światowych rankingów (np. AWRU, THE), które rzuciły światło na liczne deficyty polskich uczelni. Jedną z głównych słabości ujawnionych w rankingach był brak studentów zagranicznych, który rząd postrzegał jako wyznacznik zacofania i stałych postaw prowadzących do niepowodzenia w przystosowaniu się do dynamicznie zmieniającego się otoczenia (Pacholski 2005; Thieme 2009). Stało to w kontrze do demonstrowanych przez rząd aspiracji Polski do uzyskania miana lidera gospodarczej i politycznej modernizacji w Europie Środkowej i Wschodniej.

W Portugalii, mimo że reformy bolońskie (od 2006 r.) nadały priorytet internacjonalizacji szkolnictwa wyższego, przełom w rekrutacji nastąpił dopiero w $2014 \mathrm{r}$. wraz z uruchomieniem Narodowej Strategii Internacjonalizacji Szkolnictwa Wyższego i Legislacji ułatwiającej rekrutację studentów zagranicznych (dekret z mocą ustawy 36/2014).

Strategia została opracowana przez Ministerstwo Rozwoju Regionalnego oraz Ministerstwo Edukacji i Nauki (MADR/MEC 2014). Zamierzały one wesprzeć portugalskie szkolnictwo wyższe w przystosowaniu do tendencji globalizacyjnych w nauce i edukacji. Jak zapisano w nowej strategii, umiędzynarodowienie portugalskiego szkolnictwa wyższego jest „rozproszone, źle ukierunkowane i przynosi skromne rezultaty w porównaniu z zainwestowanymi środkami”, ponieważ „wiele instytucji prowadzi działalność w izolacji” (MADR/MEC 2014: 11-12). Z tego powodu konieczne okazało się „opracowanie narodowej strategii internacjonalizacji portugalskiego szkolnictwa wyższego, która, nie podważając autonomii instytucjonalnej, zapewni spójność rozdrobnionym wysiłkom promowanym przez kilka instytucji na własną rękę" (ss. 17-18). Strategia miała również na celu rozwiązanie problemu kakofonii politycznej „rozdźwięku w podejmowanych działaniach pomiędzy różnymi sektorami administracji publicznej i zaangażowanymi organizacjami” (s. 10). Rekrutacja zagranicznych studentów została wyróżnia jako strategiczny obszar działania. Jego celem było podwojenie liczby obcokrajowców do 2020 r. Tradycyjnie studenci zagraniczni w Portugalii pochodzili z jej byłych kolonii, a ich przyjazd na studia był bardziej motywowany bliskością polityczną i kulturową niż integracją w strategicznym obszarze działalności szkolnictwa wyższego. Podsumowując, wydaje się, że w strategii uznano potrzebę wspólnych i spójnych działań krajowych w celu podniesienia poziomu internacjonalizacji szkolnictwa wyższego w Portugalii.

Analiza pokazuje, że międzynarodowa rekrutacja studentów znalazła się w programie politycznym tych trzech krajów jako część większych pakietów reform mających na celu modernizacjęi/lub umiędzynarodowienie krajowych systemów szkolnictwa wyższego. Wcześniej ten obszar działalności pozostawiano poszczególnym uczelniom, przy czym prawie nie podejmowano dodatkowych działań wspierających ani nie mobilizowano zasobów ze strony rządu centralnego. Zmiana polityki nastąpiła na początku XXI wieku (w Norwegii, chociaż proces ten rozpocząl się w latach 80., 
przyspieszył od 2000 roku), ale czas nie jest tu przypadkowy. Mimo że procesy te rozłożyły się w czasie, to okoliczności, jakie im towarzyszyły, wykazują pewne podobieństwa. Rządy ponownie rozważyły swoje priorytety polityki szkolnictwa wyższego niejako w odpowiedzi na proces globalizacji (Kwiek i Dobbins 2017) kompleksowych reform szkolnictwa wyższego w Europie. Tak więc, choć ponad dekadę później niż w krajach centrum, szkolnictwo wyższe w krajach półperyferyjnych również znalazło się w sieci globalizacji. Co więcej zdolność przyciągania studentów z zagranicy stała się wskaźnikiem globalnej atrakcyjności i prestiżu nie tylko uczelni, ale i krajów.

\section{Hierarchia przesłanek politycznych}

Uzasadnianie rekrutacji studentów zagranicznych różni się w zależności od kontekstu. Zdecydowana większosśc wcześniejszych badań skupia się naturalnie na pionierach i liderach (Franca, Alves i Padilla 2018), warto jednak przyjrzeć się bliżej procesowi internacjonalizacji w krajach półperyferyjnych. W tym celu wykorzystamy cztery formy legitymizacji procesu internacjonalizacji (Blumenthal et al. 1996; Knight i de Wit 1995; van der Wende 1997). Jak wspomniano powyżej, zainteresowanie przyciąganiem zagranicznych studentów jest na ogół wieloaspektowe i dlatego trudno jest wskazać konkretny powód w każdym z analizowanych krajów. Jest to raczej kombinacja wszystkich czterech przesłanek, choć waga każdej z nich różni się w zależności od kraju.

Legitymizacje polityczne odgrywają bardzo ważną rolę w trzech badanych krajach, ale w zupełnie odmiennych kontekstach. Dla Norwegii polityka UE w zakresie szkolnictwa wyższego i mobilności studentów miała kluczowe znaczenie dla kształtowania norweskiej polityki zagranicznej (Gornitzka i Langfeldt 2008). W przypadku norweskim współpraca z UE znajduje silniejsze odzwierciedlenie w mobilności studenckiej niż w kwestii stopni naukowych.

Norwegia, oprócz UE, ściśle współpracuje z wieloma krajami, zwłaszcza z USA i krajami BRIC, w szczególności z Rosją (Wiers-Jenssen i Sandersen 2017). Tradycyjnie skoncentrowano się na solidarności międzynarodowej i budowaniu potencjału w krajach rozwijających się, w tym na programach finansowania publicznego i stypendiach dla studentów z krajów rozwijających się. Takie programy na styku polityki edukacyjnej i polityki pomocy zagranicznej nadal istnieją, ale zostały zreformowane w ostatnich latach, co spowodowało spadek liczby studentów z krajów rozwijających się. Jednak szeroki wachlarz regionów, z którymi Norwegia współpracuje, pokazuje, że przesłanki polityczne są silną legitymizacją dla działań zmierzających do umiędzynarodowienia szkolnictwa wyższego w Norwegii. Nieco inny jest kontekst tych działań w Polsce, która dąży do zwiększenia swojego statusu i roli w regionie krajów Europy Środkowej i Wschodniej, ale również jako nowy członek Unii Europejskiej, 
aspirując do pełnienia znacznie większej roli w Europie (Kołodko 2009). Przez lata cieszyła się wizerunkiem dynamicznie rozwijającego się kraju na drodze do pełnej integracji ze światem zachodnim. Wydaje się jednak, że polskie szkolnictwo wyższe nie wykorzystuje jeszcze w pełni swojego potencjału (w szczególności odzwierciedlonego w światowych rankingach uniwersyteckich). Widać to wyraźnie w różnych dokumentach politycznych, na przykład: „Członkostwo w UE, geopolityczne położenie naszego kraju i rozwój gospodarki opartej na wiedzy to okoliczności sprzyjające internacjonalizacji szkolnictwa wyższego. Sukces w tej dziedzinie staje się szansą na rozwój szkolnictwa wyższego i wzmocnienie roli Polski w Europie i poza nią" (MNiSW 2015).

Portugalia natomiast dąży do utrzymania swojej pozycji jako miejsca docelowego dla studentów wśród krajów portugalskojęzycznych oraz do pełnienia roli pomostu pomiędzy tymi krajami a Unią Europejską, co zresztą wyrażono explicite we wspomnianej wcześniej strategii (zob. także Franca, Alves i Padilla 2018). Zainteresowany zachowaniem kulturalnych i politycznych relacji ze społecznością krajów portugalskojęzycznych (Comunidade de Países de Língua Portuguesa - CPLP) rząd portugalski subsydiuje finansowo miejsca dla studentów z byłych terytoriów portugalskich (Veiga i in. 2006). W tym kontekście język portugalski jest przedstawiany jako niepodważalny atut w rekrutacji międzynarodowej.

Strategia na rok 2014 wyraża jednak wyraźne zainteresowanie dywersyfikacją geograficzną krajów, z których pochodzą studenci zagraniczni, dostrzegając potencjał $\mathrm{w}$ wielu regionach. Równie ważne w Polsce i Portugalii wydają się być przesłanki ekonomiczne, podczas gdy w Norwegii (która jest bardziej zamożna w porównaniu z pozostałymi dwoma krajami), wydaje się to stosunkowo najmniej istotne. Wynika to częściowo z faktu, że większość uczelni wyższych to uczelnie publiczne, które w Norwegii nie pobierają opłat za naukę. W związku z tym brak jest bezpośrednich zachęt ekonomicznych do rekrutacji studentów z zagranicy. Polska i Portugalia są jednak bardziej reprezentatywne dla kategorii półperyferałów, ponieważ zmagały się z kryzysem gospodarczym, środkami oszczędnościowymi i mniejszymi wydatkami na szkolnictwo wyższe (Fonseca i in. 2015; Kwiek 2014). Postrzegają studentów zagranicznych bardziej jako tzw. cash cows (Choudaha 2017) i jako szansę na generowanie pozabudżetowych dochodów finansowych. W Portugalii dekret z mocą ustawy 36/2014 (znany również jako Statut Międzynarodowego Studenta) stanowi, że „rekrutacja studentów z zagranicy umożliwia (...) zwiększenie dochodów własnych, które mogą być wykorzystane do poprawy jakości i dywersyfikacji nauczania oraz pozytywnie oddziałuje na gospodarkę". W Polsce w projekcie nowelizacji (MNiSW 2009: 14) podkreślono, że w kilku krajach opłaty za naukę są ważnym źródłem dochodów uczelni wyższych. Stwierdzenie to zostało zilustrowane przybliżonym oszacowaniem przychodów, jakie liderzy w tym obszarze są w stanie wygenerować $\mathrm{z}$ czesnego uiszczanego przez studentów zagranicznych. Rząd wysłał do uczelni wyraźny sygnał, 
że studenci zagraniczni mogą wnieść znaczne środki finansowe do ich budżetów. Powoływanie się na argumenty finansowe w polityce prowadzonej przez rządy jest niewygodne, ponieważ te ostatnie musiałyby przyznać, że rządy krajowe nie zapewniły odpowiednich środków. Dlatego też narracje polityczne kładą większy nacisk na pojawiające się „możliwości finansowe”, jakie niesie ze sobą międzynarodowa rekrutacja studentów do szkół wyższych.

Znacznie mniej uwagi poświęca się przesłankom akademickim, których celem jest osiągnięcie międzynarodowych standardów nauczania i badań naukowych, zakładając, że internacjonalizacja wniesie wartość dodaną do jakości kształcenia. Tylko w Norwegii okazuje się to być główną siłą napędową międzynarodowej rekrutacji studentów, gdzie polityka opiera się na założeniu, że internacjonalizacja poprawia jakość szkolnictwa wyższego (Ministerstwo Edukacji i Badań Naukowych 2009, 2017). W przypadku Polski i Portugalii międzynarodowa rekrutacja studentów jest instrumentalizowana w celu osiągnięcia bardziej znaczących politycznie celów, a mianowicie zwiększenia/utrzymania pozycji i statusu krajów w różnych obszarach odniesienia (odpowiednio w Europie Środkowej i Wschodniej oraz w krajach objętych programem Uczenie się przez całe życie), a także zwiększenia dochodów finansowych uczelni. Obydwie te kwestie nie są tak naprawdę kwestiami istotnymi w Norwegii, dlatego też większy nacisk kładzie się na przesłanki naukowe. Można założyć, że kiedy ambicje polityczne i ekonomiczne kraju są spełnione, na pierwszy plan wysuwają się przesłanki akademickie.

Najmniej ważne w dyskursie politycznym są przesłanki kulturowe, odzwierciedlające troskę o różnorodność kulturową oraz poprawę zrozumienia i komunikacji międzykulturowej wśród studentów (zarówno krajowych, jak i międzynarodowych). Zarówno retoryka polityczna, jak i kluczowe dokumenty, mają tendencję do bagatelizowania aspektów kulturowych. W każdym z tych trzech krajów jest to dodatkowy i pomocniczy argument, rzadko traktowany priorytetowo. Jest on raczej postrzegany jako ogólny cel polityczny, który należy rozważyć, ale nie jako konkretna przyczyna działań politycznych. Dlatego też zainteresowanie międzynarodową rekrutacją studentów w Norwegii, Polsce i Portugalii, choć występujące w podobnych okolicznościach, wykazuje podobieństwa w zakresie uzasadnień politycznych, ale i różnice w tym, że przesłanki ekonomiczne wyróżniają Portugalię i Polskę w porównaniu z przesłankami akademickimi w Norwegii.

W oparciu o to, czy uczelnia jest postrzegana jako środek do realizacji bardziej strategicznego celu krajowego, czy też umiędzynarodowienie jest celem samym w sobie, powyższe cztery rodzaje przesłanek umiędzynarodowienia zostały pogrupowane w dwie główne kategorie: (a) instrumentalne - przesłanki polityczne i ekonomiczne oraz (b) normatywne - przesłanki kulturowe i akademickie - związane z wartościami i poprawą sytuacji w nauce. 
W dyskursie politycznym wyłania się hierarchia, która zdaje się przedkładać racjonalizacje instrumentalne nad normatywne. $Z$ wyjątkiem Norwegii, która jest krajem o wyjątkowym bogactwie gospodarczym i reputacji politycznej jako kraj stabilny i wysoko rozwinięty. Analiza pokazuje, że główne przesłanki umiędzynarodowienia nie są ukierunkowane na poprawę podstawowych aspektów szkolnictwa wyższego. Rządy w Polsce i Portugalii postrzegają umiędzynarodowienie jako narzędzie rozwiązywania wewnętrznych problemów (np. niedofinansowanie szkolnictwa wyższego lub spadek demograficzny) oraz poprawy lub utrzymania reputacji krajów czy ich pozycji na danym obszarze geograficznym (zob. np. Franca, Alves i Padilla 2018). To, co tradycyjnie leżało u podstaw internacjonalizacji szkolnictwa wyższego, a mianowicie wzbogacanie różnorodności kulturowej na kampusie dla celów akademickich (Opper, Teichler i Carlson 1990; Altbach i Teichler 2001) stało się jedynie efektem ubocznym. Ponadto analiza przesłanek w polityce publicznej ujawnia dwa odmienne podejścia do problemu internacjonalizacji szkolnictwa wyższego: podejście normatywne, które podkreśla wartość samą w sobie tego procesu oraz instrumentalne, które korzysta z umiędzynarodowienia dla osiągnięcia innych korzyści. Przesłanki normatywne nie były sztandarowymi motywami kierującymi politykę szkolnictwa wyższego na tory międzynarodowe w Polsce i Portugalii, inaczej niż w Norwegii.

\section{Instrumenty polityki publicznej}

W odróżnieniu od wielu innych reform szkolnictwa wyższego, ukierunkowanie na umiędzynarodowienie miało raczej miękki charakter, głównie w formie przekonywania oraz zachęt ekonomicznych (Vedung 1998). Pierwszym krokiem, który otworzył szansę na internacjonalizację w Norwegii, Portugalii i Polsce, było uznanie, że nie jest to wyłącznie obowiązek poszczególnych uczelni. Istnieje wiele aspektów internacjonalizacji wykraczających poza kompetencje poszczególnych instytucji, które warunkują zdolność do przyjmowania zagranicznych studentów, np. migracja, kwestie konsularne lub inne kwestie polityczne. Wykraczają one zdecydowanie poza możliwość oddziaływania szkół wyższych. Włączenie się państwowych agencji (albo autonomicznych aktorów finansowanych z publicznych pieniędzy) stanowiło zasadniczą zmianę. Osiągnięto to dzięki strategiom krajowym (informacje lub „kazania" o mocy przekonywującej) oraz dzięki stworzeniu infrastruktury przeznaczonej do wspierania tego nowego obszaru polityki, szczególnie potrzebnej ze względu na fakt, że kraje, o których mowa, miały niewielkie doświadczenie rekrutowania studentów poza swoimi granicami.

W Norwegii Ministerstwo Edukacji i Badań Naukowych było siłą napędową polityki internacjonalizacji szkolnictwa wyższego, co ilustruje szereg dokumentów politycznych opracowanych od lat osiemdziesiątych. Centrum Współpracy Międzynarodowej 
w Dziedzinie Edukacji (SIU) zostało założone w 2004 roku i promuje współpracę międzynarodową oraz mobilność na wszystkich poziomach edukacji. SIU prowadzi kampanię Study in Norway (zob. www.studyinnorway.no), promującą Norwegię jako miejsce nauki, łączącą wysoką jakość kształcenia z bezpieczeństwem i „egzotyką” Norwegii, taką jak krajobraz i przyroda. Jest to wyraźny przykład uciekania się do budowy marki kraju i marketingu w celu zwiększenia swojej atrakcyjności dla studentów zagranicznych. SIU przejęła również administrowanie kilkoma krajowymi umowami o współpracy i programami skierowanymi do studentów z krajów rozwijających się, administrowanymi wcześniej przez Ministerstwo Spraw Zagranicznych.

W Portugalii Ministerstwa Rozwoju Regionalnego oraz Edukacji i Nauki wspólnie zainicjowały długo oczekiwaną krajową strategię internacjonalizacji szkolnictwa wyższego (MEC/MADR 2014), wypełniając polityczną lukę w koordynacji polityk i działań uczelni w tym obszarze.

Strategia zawiera szereg zaleceń, z których najistotniejsze to: odpowiednia promocja kraju i jego instytucji, strategie współpracy z określonymi regionami świata (poza Wspólnotą Państw Portugalskojęzycznych), lepsze i kompleksowe informowanie potencjalnych kandydatów, usprawnienie procedur biurokratycznych w zakresie uzyskiwania wiz, zakwaterowania, numerów podatkowych itp., ponadto stworzenie „zielonego kanału” przyjmowania międzynarodowych studentów w celu ułatwienia im wjazdu i pobytu w Portugalii, zwiększenie oferty edukacyjnej w języku angielskim itd.

Ponadto CRUP (organ przedstawicielski czternastu uniwersytetów publicznych) stworzył inicjatywę Uniwersytety Portugalskie i korzystając z pomocy innych podmiotów (rząd, Instytut Camões, portugalska Agencja Inwestycji Zagranicznych i Handlu [AICEP], Turystyka Portugalii, ambasady itp.), określono priorytetowe rynki docelowe (Angola, Brazylia, Chiny, Kolumbia, Ekwador, Luksemburg, Makau, Mozambik i Peru). Zapewniono jej finansowanie UE, stworzono markę i stronę internetową (http://www.universitiesportugal.com) oraz ustalono harmonogram wprowadzania do obrotu i promocji w krajach docelowych (Assuncao 2017). Nowo utworzona strona internetowa przedstawia przystępne cenowo życie, opiekę zdrowotną, otwartość społeczeństwa i bezpieczeństwo jako zalety wyboru Portugalii w porównaniu z innymi miejscami docelowymi. Instytucje politechniczne planują również podobną strategię wspólnej promocji za granicą (Mourato 2016).

Do 2016 r. polski rząd nie miał jasnej strategii internacjonalizacji szkolnictwa wyższego, nie istniał nawet jeden spójny dokument programowy. Zamiast tego kolejne rządy podejmowały różne, często spontaniczne, w dużej mierze nieskoordynowane, a nawet doraźne, działania, aby zamanifestować swoje zaangażowanie na rzecz zwiększenia liczby studentów zagranicznych. Na przykład w 2011 r. Prezydent RP Bronisław Komorowski podkreślił ogromne znaczenie internacjonalizacji szkolnictwa wyższego i nauki w przemówieniu do środowiska akademickiego: „W dobie kryzysu 
demograficznego musimy znaleźć sposób na przyciągnięcie międzynarodowych studentów. To dla nas duże wyzwanie i sprawdzian, czy Polska jest w stanie konkurować na rynku edukacyjnym”. To mocne stwierdzenie podzielała w pełni Barbara Kudrycka - ówczesna Minister Nauki i Szkolnictwa Wyższego - ale nie pozostawiła wątpliwości, że rząd nie sfinansuje agencji ds. międzynarodowej wymiany akademickiej. Jest to przykład pustych gestów i często życzeniowych deklaracji politycznych, które stanowiły jedynie fasadę realnych działań. Jednak Konferencja Rektorów Akademickich Szkół Polskich (KRASP) (2005), przy wsparciu Ministerstwa Edukacji i Ministerstwa Spraw Zagranicznych, stworzyła program Study in Poland prowadzony przez Fundację Perspektywy i przez prawie dekadę to właśnie Perspektywy wspierały poszczególne uczelnie w pionierskich próbach rozwoju rekrutacji międzynarodowej.

Oczywiście program Study in Poland miał wsparcie władz, ale umiędzynarodowienie było wówczas kwestią peryferyjną w polityce publicznej. Bardziej centralną rolę nadano mu w projekcie nowelizacji ustawy - Prawo o szkolnictwie wyższym (MNiSW 2009), ale dopiero w 2015 r. Ministerstwo Nauki i Szkolnictwa Wyższego opublikowało odrębny dokument (MNiSW 2015), zatytułowany Program umiędzynarodowienia szkolnictwa wyższego, w którym uznano umiędzynarodowienie (w szczególności przyjęcie studentów zagranicznych) za szansę dla polskich uczelni. Wywołało to większe zainteresowanie polityczne szeroką gamą aspektów internacjonalizacji uczelni, w związku z czym kolejny minister powołał grupę ekspertów, którzy przedstawili rekomendacje i wytyczne dla uczelni wyższych (MNiSW 2016).

Ograniczenie się jedynie do informacji jako instrumentu polityki może zwiększyć świadomość, ale niekoniecznie musi prowadzić do realnych zmian. Dlatego po wypowiedziach politycznych wyrażonych w dokumentach strategicznych (MEC/ MADR 2014; Ministerstwo Edukacji i Badań Naukowych 2009; MNiSW 2015, 2016) rządy uciekły się do bardziej „przymusowych” środków w postaci aktów prawnych. Na przykład polski rząd wprowadził nowe specjalne przepisy dla studentów zagranicznych, takie jak specjalny rodzaj wiz studenckich oraz złagodzone przepisy dla studentów mieszkających w regionach przygranicznych. Podobne udogodnienia prawne wprowadzono zresztą w Portugalii. Już przed 2014 r. ustawodawstwo imigracyjne poprawiło sytuację studentów zagranicznych, wprowadzając Niebieską kartę UE dla wysoko wykwalifikowanych cudzoziemców, zgodnie z zaleceniami UE. W 2012 r. umowy między uniwersytetami a Służbą ds. Cudzoziemców i Granic (SEF) doprowadzily do uproszczenia procedur przyjmowania i wydawania zezwoleń dla studentów zagranicznych (Fonseca i in. 2015).

Jednakże aktem prawnym, który wprowadził zmiany, był Statut studenta międzynarodowego z 2014 r. Poza możliwością łatwiejszego wjazdu na terytorium Portugalii stworzył on również możliwość pobierania przez instytucje publiczne wyższych opłat za naukę dla studentów zagranicznych (spoza UE), biorąc pod uwagę rzeczywiste 
koszty kształcenia. Niemniej jednak utrzymano specjalny program stypendialny dla studentów pochodzących z portugalskojęzycznych krajów afrykańskich i Timoru Wschodniego w celu zachowania uprzywilejowanych stosunków z tymi krajami. Program ten nie został jeszcze wdrożony (Franca, Alves i Padilla 2018). Mimo że Statut ma formę aktu prawnego, może on również działać jako instrument gospodarczy. Na koniec warto wspomnieć, że w rezolucji Rady Ministrów 78/2016 nałożono na Dyrekcję Generalną ds. Szkolnictwa Wyższego (w ścisłej współpracy z uczelniami i AICEP) obowiązek rozpowszechniania oferty edukacyjnej uczelni portugalskich poprzez portal internetowy Study in Portugal (http://www.studyinportugal.edu.pt).

Ostatnimi, ale nie najmniej ważnymi z nich, były instrumenty ekonomiczne (marchewka). W przypadku uniwersytetów zyski finansowe stały się jedną z głównych sił napędowych pozyskiwania studentów zagranicznych. W Polsce od $2017 \mathrm{r}$. zmiany w algorytmie finansowym uniwersytetów publicznych faworyzują studentów zagranicznych i stanowią dla nich silną zachętę do zmiany strategii rekrutacji. Jest to ważne, ponieważ przez dziesięciolecia polskie uczelnie były głęboko osadzone w kontekście narodowym i zorientowane na rekrutację loklanych studentów. Proces internacjonalizacji pozostawał w sprzeczności z długoletnią polską tradycją akademicką, a dla tak autonomicznych i luźno powiązanych organizacji (Weick 1976) jak uniwersytety tylko atrakcyjne środki finansowe mogły skutecznie zmienić głęboko zakorzenione wzory rekrutacyjne. Oprócz zmiany algorytmu finansowego, rząd powołał nową krajową agencję (NAWA), aby przejęła odpowiedzialność za wymianę akademicką, której powstanie zainspirowane było przez DAAD w Niemczech, Nuffic w Holandii czy Campus France. Istnieje ogromna nadzieja, że NAWA będzie odgrywać kluczową rolę w stymulowaniu wymiany studentów i pracowników naukowych.

W pierwszym roku (2018) NAWA dysponuje stosunkowo skromnym budżetem w wysokości $35 \mathrm{mln}$ euro, ale po raz pierwszy rząd przyznał ukierunkowane fundusze na internacjonalizację ( $w$ tym dwustronne programy wymiany studentów i programy stypendialne dla studentów zagranicznych), a także obiecał zwiększać budżet w miarę ogłaszania większej liczby programów dla studentów (i pracowników naukowych). W Portugalii Statut studenta międzynarodowego, otwierający możliwość pobierania wyższego czesnego, działa jako potężny instrument polityczny, który skutkuje bardziej skoordynowanymi strategiami rekrutacji przez instytucje, $\mathrm{w}$ tym również z regionów świata, z których dotychczas nie rekrutowano studentów do portugalskich uczelni. Norwegia jest natomiast przykładem kraju zamożnego, w którym instrumenty finansowe mają ograniczony wpływ na zachowanie podmiotów publicznych. Bezpośrednie zachęty ekonomiczne do rekrutacji studentów z zagranicy są niewielkie. Opłaty za naukę nie są pobierane w uczelniach publicznych, ale otrzymują one niewielką premię ekonomiczną za każdego przyjętego zagranicznego studenta. Instytucje reagują na ogół na rządową politykę internacjonalizacji, chociaż bezpośrednie zachęty 
ekonomiczne są ograniczone. Warto podkreślić, że brak opłat za naukę również zwiększa atrakcyjność dla studentów zagranicznych.

Podsumowując, we wszystkich trzech analizowanych krajach uczynienie z międzynarodowej rekrutacji celu w polityce publicznej i zaprojektowanie instrumentów polityki ukierunkowanych na aktywną rekrutację stanowiło punkt zwrotny w procesie umiędzynarodowienia szkolnictwa wyższego. Zintegrowała ona (wcześniej rozdrobnioną) działalność różnych podmiotów, w tym również spoza szkolnictwa wyższego oraz samych uczelni. Rządy wszystkich trzech państw sygnalizują oczekiwania, że instytucje powinny poszerzyć swoje horyzonty i zastanowić się nad rekrutacją talentów z całego świata. Rządowe wskazówki mogą być przekonywujące, ale stają się bardziej skuteczne, jeśli uzupełnia je bardziej „przymusowy” wpływ wynikający z ram prawnych. W Polsce i Portugalii nowe regulacje były ukierunkowane na podmioty i ich politykę w szkolnictwie wyższym oraz poza nim: głównie w zakresie migracji i polityki wizowej. Pozwoliło to na usunięcie wielu (ale na pewno nie wszystkich) wewnętrznych barier, które uniemożliwily zagranicznym studentom przyjazd do tych krajów. Wreszcie algorytmy finansowania i zachęty finansowe pochodzące od studentów opłacających studia lub specjalne finansowanie strumieniowe miały na celu motywowanie uczelni do reorientacji ich strategii w celu pozyskiwania większej liczby studentów zagranicznych.

\section{Dyskusja i wnioski}

W artykule zbadano podejścia zastosowane w celu przyciągnięcia i rekrutacji międzynarodowych studentów w trzech krajach: Norwegii, Polsce i Portugalii, rzucając tym samym światło na strategie krajowe z regionów półperyferyjnych oraz na ich przewagę konkurencyjną.

Nadanie internacjonalizacji szkolnictwa wyższego politycznych priorytetów oraz nacisk na rekrutację obcokrajowców to fenomen ostatnich kilku lat (poza Norwegią) powodujący inwestycję większych zasobów w każdym z badanych krajów. Ministerstwa odpowiedzialne za szkolnictwo wyższe były głównymi promotorami międzynarodowej rekrutacji studentów, często korzystając z pomocy innych instytucji, np. krajowych agencji lub organizacji, którym powierzono zadanie budowania marki kraju i systemu szkolnictwa wyższego.

Strategie te opierały się na wskazówkach rządowych jako instrumencie polityki (Vedung 1998), wykorzystując retorykę do wpływania na uczelnie w celu ich większego zaangażowania w proces umiędzynarodowienia. Duży wpływ miały również zmiany legislacyjne, choć największy (w przypadku Polski i Portugalii) wpływ miały instrumenty ekonomiczne w postaci zachęt finansowych. Trzeba jednak zaznaczyć, że wpływ na zwiększenie liczby studentów miał zarówno opór Norwegii przed wprowadzeniem 
opłat dla studentów zagranicznych, jak i zmiany w Portugalii, gdzie ostatnie przepisy prawne stworzyły różne zasady przyjmowania studentów zagranicznych, od których pobierane są obecnie wyższe opłaty, co sprawia, że są bardziej atrakcyjni dla uczelni.

Argumenty akademickie i polityczne (Knight i de Wit 1995) kierowały norweską strategią narodową, natomiast w Polsce i Portugalii pojawiły się przesłanki polityczne i ekonomiczne. Obserwujemy, że często jest to zbiór różnych przyczyn wpływających na internacjonalizację szkolnictwa wyższego, obejmujący argumenty instrumentalne (polityczne lub ekonomiczne), które przeważają nad argumentami normatywnymi (akademickimi i kulturowymi).

Branding krajowy (Nicolescu 2009), który poprzez strony internetowe prezentuje ofertę edukacyjną i atrakcyjne warunki kraju przyjmującego, jest prawdopodobnie jedynym podejściem wspólnym dla tych trzech krajów. Jednak atuty danego kraju, które są promowane jako czynniki przyciągające studentów zagranicznych, różnią się od tych, które są eksponowane przez największe międzynarodowe firmy rekrutacyjne (zob. Urbanovič, Wilkins i Huisman 2014). Kraje półperyferyjne nie mogą polegać na prestiżu lub marce systemu szkolnictwa wyższego, aby przyciągnąć kandydatów na studia. Mając oczywiste deficyty w tym wymiarze, wykorzystują inne zasoby (kulturowe, językowe, geograficzne, ekonomiczne itp.), w większości niezależne od szkolnictwa wyższego, poszukując jednocześnie przewag konkurencyjnych na globalnym rynku edukacyjnym. Norwegia promuje się poprzez nieskażoną przyrodę, korzysta z atrakcji bezpiecznego i dostatniego państwa opiekuńczego i utrzymuje bezpłatną edukację w przeciwieństwie do tendencji panujących w Europie i w regionie. Polska oparła swoją strategię na centralnej roli w regionie Europy Środkowo-Wschodniej jako ostoi stabilności gospodarczej i politycznej. Portugalia opiera się przede wszystkim na języku portugalskim, jako czynniku przyciągającym studentów z krajów portugalskojęzycznych, a także reklamuje się niskimi kosztami utrzymania, bezpieczeństwem i popularnym w świecie językiem. Jednocześnie próbuje poszerzyć pulę studentów zagranicznych poza studentów pochodzących z byłych kolonii.

Można zatem wyciągnąć wniosek, że na globalnym rynku edukacyjnym kraje półperyferyjne są konkurencyjne przede wszystkim w określonych regionach, z których są w stanie rekrutować relatywnie dużą liczbę kandydatów. „Regionalność” ma jednak bardzo szerokie znaczenie, w przypadku Polski jest to region Europy Wschodniej, podczas gdy Portugalia będzie regionalnym centrum dla krajów portugalskojęzycznych. Oznacza to, że kraje peryferyjne wykorzystują raczej zalety polityczne, kulturowe lub geograficzne niż walory czysto edukacyjne.

We wszystkich tych trzech krajach odnotowano wzrost liczby studentów z zagranicy, aczkolwiek pochodzących z bardzo różnych regionów świata. Modele rekrutacji odzwierciedlają nie tylko przemyślane strategie, ale także struktury szans i więzi historyczne. Portugalia opiera się głównie na związkach z byłymi koloniami, 
podczas gdy Polska rekrutuje głównie z krajów sąsiednich, korzystając z bliskości kulturowej i językowej. Ilustrują one logikę kolonialną i logikę bliskości (Börjesson 2017), obie mają wymiar polityczny. Jednocześnie w obu przypadkach działania rządów i uczelni kierowane są logiką rynkową, związaną z przesłankami ekonomicznymi i potrzebą pozyskiwania zasobów finansowych. Norwegia częściowo kieruje się logiką bliskości, ale rekrutuje także studentów z krajów odległych (geograficznie, politycznie i kulturowo) prawdopodobnie dzięki jej unikalnym atutom, takim jak bezpłatna edukacja i dobrobyt gospodarczy, które wyróżniają ją na tle pozostałych krajów półperyferyjnych.

W przypadku Polski i Portugalii wzrost liczby studentów z zagranicy nie wynikał ze wspólnych strategii krajowych, ponieważ strategie te były nowe, nieskoordynowane i w dużej mierze doraźne. Jednak w przypadku tych krajów wzrost liczby studentów zagranicznych ułatwiły przede wszystkim pozaedukacyjne okoliczności związane z powiązaniami kulturowymi i językowymi, bliskością geograficzną i dobrobytem, w połączeniu z rosnącymi aspiracjami do kształcenia w krajach o słabiej rozwiniętym systemie szkolnictwa wyższego lub w krajach o niestabilnej sytuacji (np. na Ukrainie).

Intensyfikacja działań politycznych i instytucjonalnych w tym obszarze może w dłuższej perspektywie doprowadzić do rekrutacji studentów z krajów innych niż ich tradycyjne regiony rekrutacyjne. Jednak ze względu na brak globalnie rozpoznawalnych uniwersytetów i/lub o wysokiej widoczności w międzynarodowych rankingach, przyciągnięcie dużej liczby studentów z największych krajów azjatyckich pozostaje jeszcze poza ich zasięgiem.

Głównym wnioskiem naszych analiz jest to, że kraje półperyferyjne wydają się stosować inne strategie i uciekać się do specyficznych przewag konkurencyjnych zasadniczo odmiennych od tych stosowanych przez największych graczy na rynku. Ma to wpływ na stosowane działania w celu przyciągnięcia studentów z krajów znajdujących się na obrzeżach globalnego rynku edukacyjnego. Oznacza to konieczność podkreślania przez analizowane kraje (Portugalia, Polska i Norwegia) ich szczególnych atutów, a także celowego doboru regionów i profilowanych pod ich potrzeby strategii rekrutacyjnych. Półperyferyjne kraje muszą wykorzystywać rynkowe nisze. Takie podejście wydaje się przynosić większe korzyści niż próba rywalizacji z głównymi aktorami na tym rynku, co z wielu powodów skazane jest niepowodzenie. Innym spostrzeżeniem jest wykazanie potrzeby połączenia i uspójnienia wysiłków na poziomie krajowym oraz instytucjonalnym w celu promowania systemu szkolnictwa wyższego jako całości, ponieważ niewiele poszczególnych instytucji, jeśli jakieś w ogóle, cieszy się globalną rozpoznawalnością na tyle, aby przyciągnąć dużą liczbę utalentowanych studentów. Do poddania dalszej analizie zasługują indywidualne strategie stosowane przez uczelnie w krajach półperyferyjnych, ponieważ brakuje empirycznych badań nad strategiami i działaniami poszczególnych uczelni w regionach półperyferyjnych. 


\section{Literatura}

Altbach, P.G. (2013). The International imperative in higher education. Global perspectives on higher education. Rotterdam: Sense Publishers.

Altbach, P.G. i Teichler, U. (2001). Internationalisation and exchanges in a globalized University. Journal of Studies in International Education 5(1): 5-25.

Antonowicz, D. (2012). External Influences and Local Responses. Changes in Polish Higher Education 1990-2005. W: National higher education reforms in a European context: comparative reflections on Poland and Norway, red. P. Maassen i M. Kwiek, 87-111. Frankfurt am Main: Peter Lang.

Assunção, M. (2017). Exportação do Ensino Superior. W: PortugalGlobal: A crescente internacionalização do ensino superior português, 7-8 Lisboa: AICEP.

Barnett, G.A., Lee, M., Jiang, K. i Park, H.W. (2016). The flow of international students from a macro perspective: a network analysis. Compare: A Journal of Comparative and International Education 46(4): 533-559.

Beine, M., Noël, R. i Ragot, L. (2014). Determinants of the international mobility of students. Economics of Education Review 41: 40-54.

Blumenthal, P., Goodwin, C., Smith, A. i Teichler, U. (1996). Academic mobility in a changing world: Regional and Global Trends. London: Jessica Kingsley.

Börjesson, M. (2017). The global space of international students in 2010. Journal of Ethnic and Migration studies 43(8): 1256-1275.

Choudaha, R. (2017). Are International Students 'Cash Cows'? International Higher Education, 90: $5^{-6 .}$

Cantwell, B. (2017). The geopolitics of the educational market. W: Global Rankings and the Geopolitics of Higher Education, red. E. Hazelkorn, 309-324. London: Routledge.

Caruso, R. i de Wit, H. (2015). Determinants of Mobility of Students in Europe: Empirical Evidence for the period 1998-2009. Journal of Studies in International Education 19(3): 265-282.

Cremonini, L., i Antonowicz, D. (2009). In the Eye of the Beholder? Conceptualizing academic attraction in the global higher education market. European Education 41(2): 52-74.

Cox, M. (2013). International student recruitment: policies and developments in selected countries: Sweden, Norway and Finland. The Hague: Nuffic.

DBH. (2017). Foreign students of all registered students. Accessed on 3 October at http:// dbh.nsd.uib.no/dbhvev/dokumenter/internasjonalisering/tabeller_tilstandsrapport. html\#tabell9.

Drori, G. (2015). Branding universities: Trends and strategies. International Higher Education (71): $3-5$.

European University Association. (2013). Internationalisation in European higher education: European policies, institutional strategies and EUA support. Belgium: EUA. 
Fonseca, M.L., Esteves, A. i Iorio, J. (2015). Mobilidade internacional de estudantes do ensino superior: os alunos universitários brasileiros em Portugal. W: Vagas atlânticas: migrações entre Brasil e Portugal no início do século XXI, red. J. Peixoto, B. Padilla, J.C. Marques, i P. Góis, 149-175. Lisboa: Editora Mundos Sociais.

França, T., Alves, E. i Padilla, B. (2018). Portuguese policies fostering international student mobility: a colonial legacy or a new strategy?. Globalisation, Societies and Education, 1-14. Gornitzka, Å. i Langfeldt, L. (2008). The internationalisation of national knowledge policies. W: Borderless Knowledge, red. A. Gornitzka i L. Langfeldt. Dordrecht: Springer.

GUS. (2016). Higher education institutions and their finances in 2015. Warsaw: GUS.

Knight, J. i de Wit, H. (1995). Strategies for internationalisation of higher education: Historical and conceptual perspectives. W: Strategies for internationalisation of higher education. A comparative study of Australia, Canada, Europe, and the United States, red. H. de Wit, 5-32. Amsterdam: European Association for International Education.

Kołodko, G. (2009). A two-thirds of success. Poland's post-communist transformation 1989-2009. Communist and Post-communist Studies 42(3): 325-351

Kondakci, Y. (2011). Student mobility reviewed: Attraction and satisfaction of international students in Turkey. Higher Education 62(5): 573.

Kwiek, M. (2014). Structural Changes in the Polish Higher Education System (1990-2010): A Synthetic View. European Journal of Higher Education, 4: 266-280.

Kwiek, M. i Dobbins, M. (2017). Europeanisation and globalisation in higher education in Central and Eastern Europe: 25 years of changes revisited (1990-2015). European Education Research Journal, 16(5): 519-528.

Opper, S., Teichler, U. i Carlson, J. (1990). The Impact of Study Abroad Programmes on Students and Graduates. London: Jessica Kingsley Publishers.

Llewellyn-Smith, C. i McCabe, V.S. (2008). What is the attraction for exchange students: the host destination or the host university? Empirical evidence from a study of an Australian University. International Journal of Tourism Research 10: 593-607.

MADR/MEC. (2014). Uma estratégia para a internacionalização do ensino superior português [A strategy for the internationalisation of Portuguese Higher Education]. Lisbon: Ministry of Regional Development and Ministry of Education.

Mazzarol, T. i Soutar, G.N. (2002). The "push-pull” Factors Influencing International Student Selection of Education Destination." International Journal of Educational Management 16(2): 82-90.

Ministry of Education and Research. (2009). White paper no 14 (2008-2009). Internasjonalisering av utdanning [Internationalisation of education]. Oslo: Ministry of Education.

Ministry of Education and Research. (1985). Om høyere utdanning [On higher education] White paper no 19.

Ministry of Education and Research. (2001). Gjør din plikt, krev din rett. Kvalitetsreform av høyere utdanning [Do your duty, demand your rights. Quality reform in higher education]. White paper no 27. 
Ministry of Education and Research. (2009). Internasjonalisering av utdanning [Internationalisation of Education] White paper no 14.

Ministry of Education and Research. (2016). Tilstandsrapporten for hoyere utdanning 2016. [Status report for higher education 2016]. Oslo: Ministry of Education.

Ministry of Education and research. (2017). Kultur for kvalitet i høyere utdanning [Culture for Quality in higher education]. White paper no 11 2016-2017. Oslo: Ministry of Education and research.

MNiSW [Ministry of Science and Higher Education]. (2009a). Partnerstwo dla Wiedzy. Reforma szkolnictwa wyższego $w$ Polsce. Warsaw: MNiSW.

MNISW. (2009b). Zatożenia do nowelizacji ustawy - Prawo o szkolnictwie wyższym oraz ustawy o stopniach naukowych i tytule naukowym oraz o stopniach i tytule $w$ zakresie sztuki. Warsaw: MNiSW.

MNISW. (2015). Program umiędzynarodowienia szkolnictwa wyższego. MNiSW, Warszawa. Mosneaga, A. i Agergaard, J. 2012. Agents of internationalisation? Danish universities' practices for attracting international students. Globalisation, Societies and Education 10(4): $519-538$.

Mourato, J. (2016). Ensino Superior Politécnico \& internacionalização. Público, 23 February 2016.

Nicolescu, L. (2009). Applying Marketing to Higher Education: scopes and limits. Management \& Marketing 4(2): 35-44.

NIFU. (2018). Doktorgrader [Ph.d. statistics ] https://www.nifu.no/fou-statistiske/fou-statistikk/ doktorgrader/.

NOU. (1989). Grenseløs læring [Borderless knowledge] (1989). Green paper 1989: 13.

OECD. (2016). Education at a Glance. OECD Indicators. Paris: OECD.

OECD. 2017. Education at a Glance. OECD Indicators. Paris: OECD.

Pacholski, L. (2005). Jakie uniwersytety? Nauka 1: 147-156.

Perkins, R. i Neumayer, E. (2014). Geographies of educational mobilities: Exploring the uneven flows of international students. The Geographical Journal 180(3): 246-259.

Pinheiro, R. i Antonowicz, D. (2014). Opening the gates or coping with the flow? Governing access to higher education in Northern and Central Europe. Higher Education 70(3): 299-313.

Sarpebakken, B. (2016). Doktorgradsstatistikk. Tabeller og figurer. [Doctoral statistics. Tables and figures] Oslo: Nordic Institute for Studies in Innovation, Research and Education. http://www.nifu.no/wp-content/uploads/2017/03/Figurer-og-tabeller-1980-2016-NY.pdf.

Salerno, C. (2007). A Service Enterprise: The Market Vision. W: University Dynamics and European Integration, red. P.A. Maassen i J. Olsen, 119-135. Dordrecht: Springer.

SIU. (2013). Internasjonal profil? Strategier for Internasjonalisering ved norske universiteter og høyskoler [International profile? Strategies for internationalisation at Norwegian universities and colleges]. Bergen: Norwegian Centre for International cooperation in Education. 
SIU. (2016). Mobilitetsrapport 2016 [Mobility report 2016]. Bergen: Norwegian Centre for International cooperation in Education.

Sin, C., Veiga, A. i Amaral, A. (2016). European Policy Implementation and Higher Education: Analysing the Bologna Process. London: Palgrave.

Stier, J. (2004). Taking a critical stance toward internationalisation ideologies in higher education: idealism, instrumentalism and educationalism. Globalisation, Societies and Education 2(1): 1-28.

Sursock, A. (2015). Trends 2015: Learning and Teaching in European Universities. Brussels: EUA.

Thieme, J. (2009). Szkolnictwo wyższe: wyzwania XXI wieku: Polska, Europa, USA. Difin, Warszawa.

Varghese, N. V. (2008). Globalization of higher education and cross-border student mobility. Paris: Unesco.

Vedung, E. (1998). Policy Instruments: Typologies and Theories. W: Carrots, Sticks and Sermons: Policy Instruments and Their Evaluation, red. M.-L. Bemelmans-Videc, R.C. Rist i E. Vedung, 21-58. New Brunswick and London: Transaction Publishers.

van der Wende, M. (1997). Missing links. The relationship between National Policies for Internationalisation and those for Higher Education in general. W: National Policies for the Internationalisation of Higher Education in Europe, red. Kälvemark i van der Wende. Stockholm: National Agency of Higher Education.

van der Wende, M. (2010). Internationalisation of higher education, Internationalisation of higher education. W: International encyclopedia of education, red. P.L. Peterson, E.L. Baker i B. McGaw, 540-545. Oxford: Elsevier.

Wallerstein, I.M. (1974). The modern world-system. New York: Academic Press.

Weick, K.E. (1976). Educational organizations as loosely coupled systems. Administrative science quarterly, 1-19.

Wiers-Jenssen, J. i Sandersen, H.T. (2017). The Norwegian Framework for Educational Cooperation with Russia: Educational Policy with a Hint of Foreign Affairs'. W: Higher Education in the High North: Academic Exchanges between Norway and Russia, red. M. Sundet, P.A. Forstorp i A. Örtenblad. Dordrecht: Springer.

Wiers-Jenssen, J. (2018). Paradoxical Attraction? Why an Increasing Number of International Students Choose Norway. Journal of Studies in International Education, https://doi. org/10.1177/1028315318786449.

de Wit, H., F., Hunter, L., Howard i Egron-Polak, E. (2015). European Parliament study on internationalisation of higher education. Brussels: European Union.

\section{Podziękowania}

Chcielibyśmy podziękować redakcji Higher Education Policy za możliwość publikacji polskojęzycznej wersji tego artykułu, a także Mari Elken za lekturę draftu tego 
dokumentu (w wersji anglojęzycznej) i za jej cenne krytyczne opinie, które pomogły nam poprawić tekst. Niniejszy dokument został opracowany przy wsparciu stypendium podoktoranckiego portugalskiej Fundacji na Rzecz Nauki i Technologii (FCT), SFRH/BPD/85724/2012 oraz przy wsparciu ze Narodowego Centrum Nauki (NCN), grant badawczy (UMO-2013/10/M/HS6/00561).

\section{Załącznik 1.}

Tabela A1. Liczba przyjeżdżających do Norwegii studentów zawiera pełnocyklowych studentów, którzy ukończyli szkoły średnie poza Norwegią i przenieśli się do Norwegii mniej niż 5 lat przed rozpoczęciem studiów

\begin{tabular}{lcccc}
\hline \multirow{2}{*}{ Kraj pochodzenia } & $\mathbf{2 0 1 3 / 2 0 1 4}$ & \multicolumn{3}{c}{$\mathbf{2 0 1 6 / 2 0 1 7}$} \\
\cline { 2 - 5 } & $\mathbf{N}$ & $\mathbf{\%}$ & $\mathbf{N}$ & $\mathbf{\%}$ \\
\hline TOTAL & 9240 & 100 & 9385 & 100 \\
\hline Sweden & 758 & 8.2 & 692 & 7.3 \\
\hline China & 745 & 8.1 & 494 & 5.2 \\
\hline Germany & 440 & 4.8 & 441 & 4.7 \\
\hline Russia & 608 & 6.6 & 397 & 4.2 \\
\hline Nepal & 429 & 4.6 & 395 & 4.2 \\
\hline Denmark & 245 & 2.7 & 312 & 3.3 \\
\hline India & - & - & 301 & 3.2 \\
\hline Iran & 453 & 4.9 & 279 & 3.0 \\
\hline Poland & 232 & 2.5 & 251 & 2.7 \\
\hline USA & 204 & 2.2 & 247 & 2.6 \\
\hline Ethiopia & 251 & 2.7 & 228 & 2.4 \\
\hline Ukraine & 221 & 2.4 & 225 & 2.4 \\
\hline Pakistan & - & - & 209 & 2.2 \\
\hline Other & 4654 & 51.4 & 4914 & 52.4 \\
\hline
\end{tabular}

Źródło: https://www.ssb.no/utdanning/artikler-og-publikasjoner/_attachment/335552? ts $=160$ b6 5 dba20.

Tabela A2. Studenci zagraniczni w Polsce (2013/2014) i (2016/2017)

\begin{tabular}{lcccc}
\hline \multirow{2}{*}{ Kraj pochodzenia } & $\mathbf{2 0 1 3 / 2 0 1 4}$ & \multicolumn{3}{c}{$\mathbf{2 0 1 6 / 2 0 1 7}$} \\
\cline { 2 - 5 } & $\mathbf{N}$ & $\mathbf{\%}$ & $\mathbf{N}$ & $\mathbf{\%}$ \\
\hline TOTAL & 35983 & 100 & 65793 & $100 \%$ \\
\hline Ukraine & 15123 & 42 & 35584 & 54.08 \\
\hline Belarus & 3743 & 10.4 & 5119 & 7.78 \\
\hline Norway & 1580 & 4.33 & 1531 & 2.32 \\
\hline Spain & 1361 & 3.78 & 1607 & 2.44 \\
\hline Sweden & 1251 & 3.47 & 1242 & 1.88 \\
\hline
\end{tabular}




\begin{tabular}{lcccc}
\hline \multirow{1}{*}{ Kraj pochodzenia } & $\mathbf{2 0 1 3 / 2 0 1 4}$ & \multicolumn{3}{c}{$\mathbf{2 0 1 6 / 2 0 1 7}$} \\
\cline { 2 - 5 } & $\mathbf{N}$ & $\mathbf{\%}$ & $\mathbf{N}$ & $\mathbf{\%}$ \\
\hline Lithuania & 965 & 2.68 & 802 & 1.21 \\
\hline Turkey & 882 & 2.45 & 1471 & 2.23 \\
\hline USA & 814 & 2.26 & 769 & 1.16 \\
\hline Russia & 810 & 2.25 & 1055 & 1.6 \\
\hline Germany & 743 & 2.06 & 1173 & 1,78 \\
\hline Saudi Arabia & 688 & 1.91 & 871 & 1.32 \\
\hline China & 670 & 1.86 & 953 & 1.44 \\
\hline Czech Republic & 626 & 1.7 & 1061 & 1.61 \\
\hline Other & 6727 & 18 & 12555 & 19.08 \\
\hline
\end{tabular}

Źródło: własne kalkulacje w oparciu o GUS $(2014,2017)$.

Tabela A3. Studenci zagraniczni w Portugalii (2013/2014) i (2016/2017)

\begin{tabular}{lcccc}
\hline \multirow{2}{*}{ Kraj pochodzenia } & $\mathbf{2 0 1 3} / \mathbf{2 0 1 4}$ & \multicolumn{3}{c}{$\mathbf{2 0 1 6 / 2 0 1 7}$} \\
\cline { 2 - 5 } & $\mathbf{N}$ & $\mathbf{\%}$ & $\mathbf{N}$ & $\mathbf{\%}$ \\
\hline TOTAL & 14883 & 100,0 & 22194 & 100,0 \\
\hline Brazil & 5218 & 35 & 7764 & 35,0 \\
\hline Angola & 2121 & 14 & 2916 & 13,1 \\
\hline Cape Verde & 1832 & 12 & 2267 & 10,2 \\
\hline Spain & 647 & 4 & 965 & 4,3 \\
\hline Mozambique & 483 & 3 & 751 & 3,4 \\
\hline France & 279 & 2 & 674 & 3,0 \\
\hline São Tomé and Príncipe & 317 & 2 & 661 & 3,0 \\
\hline Italy & 315 & 2 & 543 & 2,4 \\
\hline China & 148 & 1 & 488 & 2,2 \\
\hline Guinee-Bissau & 199 & 1 & 384 & 1,7 \\
\hline Germany & 205 & 1 & 327 & 1,5 \\
\hline East Timor & 257 & 2 & 326 & 1,5 \\
\hline Other & 2862 & 19 & 4128 & 18,6 \\
\hline
\end{tabular}

Źródło: własne kalkulacje w oparciu o General Directorate for Education and Science Statistics.

\section{Attracting International Students to Semi-peripheral Countries: A Comparative Study of Norway, Poland and Portugal}

\footnotetext{
ABSTRACT: The paper investigates the approaches employed for attracting international full-degree students in three countries on the periphery of Europe/the European Economic Area: Norway, Poland and Portugal. These countries, considered semi-peripheral regarding international student recruitment, have shorter traditions for incoming mobility than countries that are major recruiters
} 
and which have been the focus of previous research on attracting international students. The paper analyses national policies and strategies, focusing on their emergence, rationales and instruments. The study is comparative, aiming to find commonalities and differences in the approaches of these countries further to the changing global environment in higher education. The major finding is that semi-peripheral countries appear to employ different strategies and resort to other comparative advantages than the largest student recruiters, exploiting political, cultural or geographical aspects rather than educational assets. The findings highlight the need for these countries to identify their distinctive attraction capacities and assets, as well as to be purposeful in choosing their target recruitment regions.

KEYWORDS: international students, recruitment, periphery, policies, internationalization

CYTOWANIE: Antonowicz, D., Sin, C. i Wiers-Jenssen, J. (2019). Pozyskiwanie studentów zagranicznych do uczelni krajów półperyferyjnych. Badanie porównawcze Norwegii, Polski i Portugalii. Nauka i Szkolnictwo Wyższe. 1-2(53-54): 155-181. DOI: 10.14746/nisw.2019.1-2.5.

DOMINIK ANTONOWICZ - kieruje Katedrą Badań nad Szkolnictwem Wyższym i Nauką w Uniwersytecie Mikołaja Kopernika w Toruniu. Prowadzi badania nad polityka naukową i ustrojami instytucji akademickich.

E-mail: dominik@umk.pl

CRISTINA SIN - pracuje w Agência de Avaliação e Acreditação do Ensino Superior oraz Centre for Research in Higher Education Policies (CIPES) w Porto. Jej zainteresowania badawcze koncentrują się głównie na wpływie polityki wobec szkolnictwa wyższego na praktyki edukacyjne, w tym zwłaszcza jakość kształcenia. W ostatnich latach prowadziła badania nad problematyką implementacji Procesu Bolońskiego w portugalskim szkolnictwie wyższym.

JANNECKE WIERS-JENSSEN - pracuje w Centre for the Study of Professions Teaching and Research Oslo Metropolitan University. Zajmuje się głównie edukacją na poziomie wyższym, oraz jej związkami z rynkiem pracy. W ostatnich kilku latach coraz więcej uwagi poświęca się zjawisku umiędzynarodowienia szkolnictwa wyższego, w tym zwłaszcza obcokrajowcom studiującym w Norwegii. 